\title{
Methylobacillus pratensis sp. nov., a novel non-pigmented, aerobic, obligately methylotrophic bacterium isolated from meadow grass
}

Correspondence
Yuri A. Trotsenko
trotsenko@ibpm.pushchino.ru

\author{
Nina V. Doronina, ${ }^{1}$ Yuri A. Trotsenko, ${ }^{1}$ Tatjana V. Kolganova, ${ }^{2}$ \\ Tatjana P. Tourova ${ }^{3}$ and Mirja S. Salkinoja-Salonen ${ }^{4}$ \\ ${ }^{1}$ G.K. Skryabin Institute of Biochemistry and Physiology of Microorganisms, Russian Academy \\ of Sciences, 142290 Pushchino, Moscow region, Russia \\ ${ }^{2}$ Bioengineering Center, Russian Academy of Sciences, 117312 Moscow, Russia \\ ${ }^{3}$ Institute of Microbiology, Russian Academy of Sciences, 117312 Moscow, Russia \\ ${ }^{4}$ Department of Applied Chemistry and Microbiology, University of Helsinki, PO Box 56, \\ FIN 00014, Finland
}

\begin{abstract}
Strain $\mathrm{F} 31^{\top}$ was isolated from meadow grass (Poa trivialis L.) sampled from the city park in Helsinki. Analysis of phenotypic and genotypic properties showed the strain to be related to the group of obligately methylotrophic non-methane utilizing bacteria (methylobacteria) with the ribulose monophosphate pathway of formaldehyde assimilation. Phylogenetic analysis showed the strain to be closely related to the genus Methylobacillus, and analysis of fatty acid composition confirmed this association. Thus, on the basis of its genotypic and phenotypic properties, the isolate is proposed as a novel species of the genus Methylobacillus, Methylobacillus pratensis sp. nov., with $\mathrm{F} 31^{\top}$ as the type strain (=VKM B-2247 $\left.{ }^{\top}=\mathrm{NCIMB} 13994^{\top}\right)$.
\end{abstract}

To date, four genera have been described for the group of obligately methylotrophic non-methane utilizing bacteria (methylobacteria) with the ribulose monophosphate (RuMP) pathway of formaldehyde assimilation. All known terrestrial strains of obligate methylobacteria were placed into three genera: Methylobacillus (Yordy \& Weaver, 1977; Urakami \& Komagata, 1986), Methylophilus (Jenkins et al., 1987) and Methylovorus (Govorukhina \& Trotsenko, 1991). Marine obligate methylobacteria assigned to the genus Methylophaga (Urakami \& Komagata, 1987) are clearly distinguished from members of the genera Methylobacillus, Methylophilus and Methylovorus by their tolerance to $\mathrm{NaCl}$ (up to $10-12 \%, w / v$ ), some physiological characteristics and the low DNA G $+\mathrm{C}$ content $(38 \cdot 0-49 \cdot 0 \mathrm{~mol} \%)$. However, terrestrial and marine strains of obligate methylobacteria possess similar morphology and metabolic organization. Thus, the main criteria used to classify obligate methylobacteria into separate genera and species are their genomic and phylogenetic characteristics. Here, we present a formal taxonomic description of the newly isolated,

Published online ahead of print on 27 February 2004 as DOI 10.1099/ ijs.0.02956-0.

Abbreviation: RuMP, ribulose monophosphate.

The GenBank/EMBL/DDBJ accession number for the $16 \mathrm{~S}$ rRNA gene sequence of strain $\mathrm{F} 31^{\top}$ is $A Y 298905$. obligately methylotrophic strain $\mathrm{F} 31^{\mathrm{T}}$, which has the RuMP pathway. The name Methylobacillus pratensis sp. nov. is proposed for this isolate.

Strain $\mathrm{F} 31^{\mathrm{T}}$ was isolated from meadow grass (Poa trivialis L.) sampled from the city park in Helsinki (Finland) and grown on medium K (Doronina et al., 1998). Analyses of phenotypic and genotypic properties of the novel isolate were performed as described previously (Doronina et al., 2003). The $16 \mathrm{~S}$ rRNA gene of strain $\mathrm{F} 31^{\mathrm{T}}$ was amplified by $\mathrm{PCR}$, sequenced and screened against sequences within the GenBank database by using BLAST (http://www.ncbi.nlm. nih.gov/blast). The 16S rRNA gene sequence of strain $\mathrm{F} 31^{\mathrm{T}}$ was then aligned with a representative set of $16 \mathrm{~S}$ rRNA gene sequences obtained from recent GenBank releases, using CLUSTAL W software (Thompson et al., 1994). Positions of sequence and alignment uncertainty were omitted, and a total of 1308 nucleotides was used in the phylogenetic analysis. Phylogenetic trees were constructed by using various algorithms implemented in TREECON (Van de Peer \& De Wachter, 1994).

Cells of strain $\mathrm{F} 31^{\mathrm{T}}$ are Gram-negative, asporogenous rods $(0.5-0 \cdot 7 \times 0 \cdot 9-1 \cdot 8 \mu \mathrm{m})$ that are motile by means of a polar flagellum, and occur singly or (rarely) in pairs (Fig. 1a-c). Reproduction occurs by binary fission.

As shown in Table 1, the dominant cellular fatty acids of 

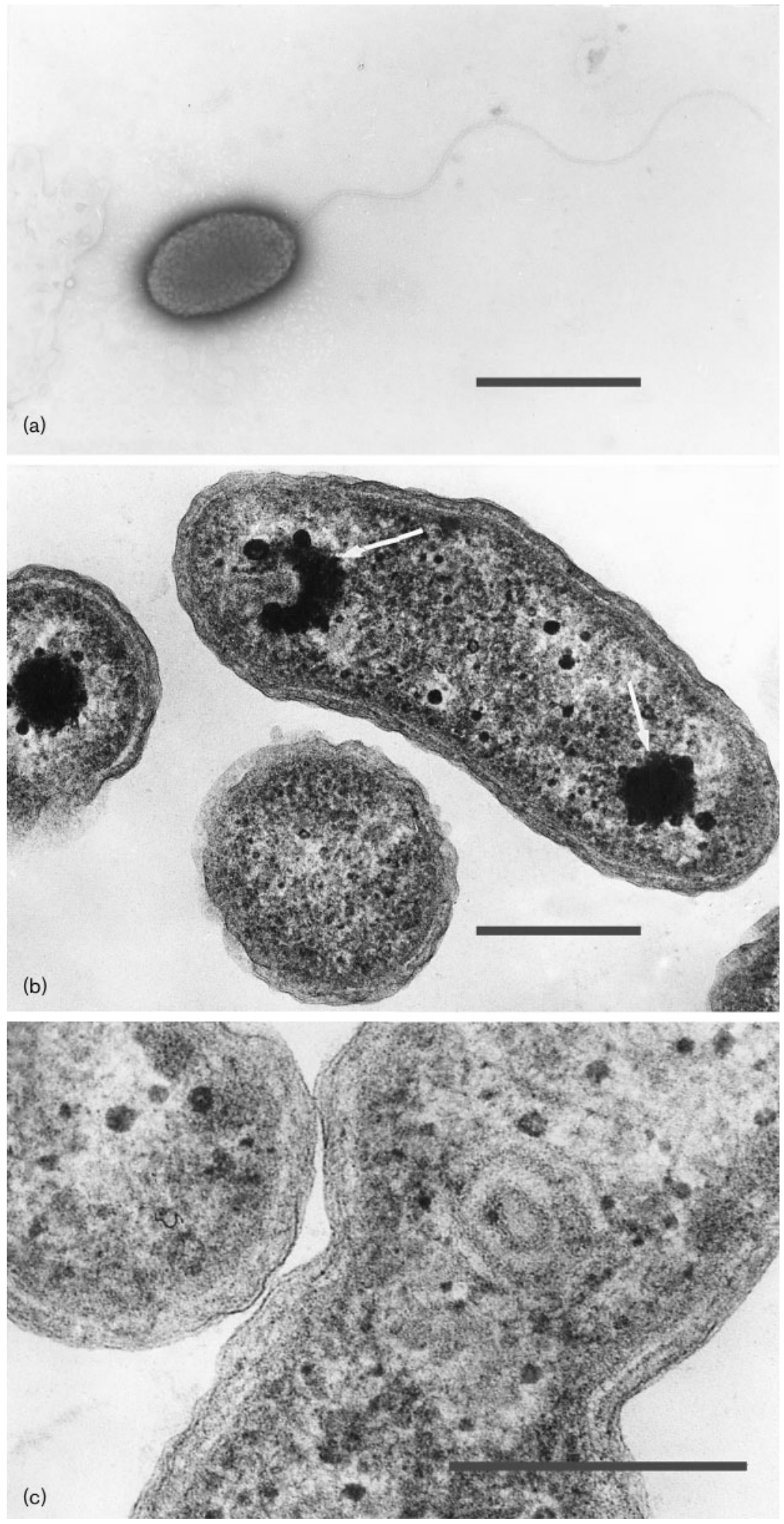

Fig. 1. Electron micrographs of strain $\mathrm{F} 31^{\top}$. (a) Negatively stained cell. (b, c) Ultra-thin sections showing cell wall structure and polyphosphate granules (arrows). Bars, $1 \mu \mathrm{m}$ (a), $0.2 \mu \mathrm{m}$ (b, c). strain $\mathrm{F} 31^{\mathrm{T}}$ are unsaturated $\mathrm{C}_{16: 1} \omega 7$ acid $(46 \cdot 6 \%)$ and straight-chain saturated $\mathrm{C}_{16: 0}$ acid $(41 \cdot 6 \%)$. The presence of 3-hydroxy fatty acids was observed, but no 2-hydroxy fatty acids were found. The data indicate a considerable similarity in the fatty acid composition of strain $\mathrm{F} 31^{\mathrm{T}}$ and the type cultures of the genus Methylobacillus, i.e. Methylobacillus glycogenes ATCC $29475^{\mathrm{T}}$ and Methylobacillus flagellatus DSM $6875^{\mathrm{T}}$. Analysis of the cellular phospholipid 
Table 1. Cellular fatty acid composition of strain $\mathrm{F} 31^{\top}$ and members of the genus Methylobacillus

Strain: 1, Methylobacillus pratensis $\mathrm{F}^{2} 1^{\mathrm{T}} ; 2$, Methylobacillus glycogenes ATCC $29475^{\mathrm{T}}$; 3, Methylobacillus flagellatus DSM $6875^{\mathrm{T}}$. Results are given as a percentage of total fatty acids. $\mathrm{C}_{19:: 0}$ (cyclopropane acid) was not present in any of the strains.

\begin{tabular}{|lrrr|}
\hline Fatty acid & $\mathbf{1}$ & $\mathbf{2}$ & $\mathbf{3}$ \\
\hline Straight-chain acids & & & \\
$\mathrm{C}_{14: 0}$ & $1 \cdot 1$ & $1 \cdot 1$ & $1 \cdot 0$ \\
$\mathrm{C}_{15: 0}$ & $0 \cdot 9$ & $0 \cdot 5$ & $0 \cdot 6$ \\
$\mathrm{C}_{16: 0}$ & $41 \cdot 6$ & $43 \cdot 4$ & $41 \cdot 4$ \\
$\mathrm{C}_{16: 1}$ & $46 \cdot 6$ & $42 \cdot 5$ & $44 \cdot 6$ \\
$\mathrm{C}_{17: 0}$ & $0 \cdot 7$ & $0 \cdot 5$ & $0 \cdot 5$ \\
$\mathrm{C}_{18: 0}$ & $1 \cdot 2$ & $0 \cdot 8$ & $0 \cdot 7$ \\
$\mathrm{C}_{19: 1}$ & $1 \cdot 3$ & $4 \cdot 6$ & $4 \cdot 0$ \\
Cyclopropane acid $_{\mathrm{C}_{17: 0}}$ & & & \\
Hydroxy acid & $1 \cdot 4$ & $1 \cdot 3$ & $2 \cdot 1$ \\
3-OH C & & & \\
& $5 \cdot 2$ & $5 \cdot 3$ & $5 \cdot 1$ \\
\hline
\end{tabular}

composition revealed the presence of phosphatidylethanolamine (65\%), phosphatidylglycerol (20\%), diphosphatidylglycerol (cardiolipin) $(10 \%)$ and minor amounts of phosphatidylserine, phosphatidic acid and an unidentified phospholipid. Phosphatidylcholine and lysolecithin were not found.

The enzyme profiles of methanol- or methylamine-grown cells indicated that strain $\mathrm{F} 31^{\mathrm{T}}$ oxidizes methanol to formaldehyde by means of an inducible pyrroloquinoline quinone (PQQ)-linked methanol dehydrogenase (Table 2). Methylamine dehydrogenase PQQ and amine oxidase were absent in methylamine-grown cells. Alternatively, the isolate possessed an inducible $\gamma$-glutamylmethylamide synthetase and $\mathrm{N}$-methylglutamate synthase/lyase, the specific enzymes of the $\mathrm{N}$-methylglutamate pathway producing formaldehyde, which is further oxidized by glutathionedependent formaldehyde dehydrogenase to formate. The latter is partly oxidized to $\mathrm{CO}_{2}$ by NAD-dependent formate dehydrogenase. Formaldehyde assimilation occurs via the RuMP cycle (Entner-Doudoroff variant), as confirmed by the presence of 3-hexulose phosphate synthase and 2-keto3-deoxy-6-phosphogluconate aldolase. Glucose-6-phosphate dehydrogenase and 6-phosphogluconate dehydrogenase are active with both $\mathrm{NAD}^{+}$and $\mathrm{NADP}^{+}$. Rather high levels of these enzymes indicate the preferential oxidation of formaldehyde to $\mathrm{CO}_{2}$ via the dissimilatory hexulose phosphate cycle, which provides the methylotroph with the reduced equivalents and energy for biosynthesis. However, we cannot rule out the same potential role of the tetrahydromethanopterin $\left(\mathrm{H}_{4} \mathrm{MPT}\right)$-dependent oxidation pathway in formaldehyde dissimilation in our isolate because high activities of methenyl $\mathrm{H}_{4} \mathrm{MPT}$ cyclohydrolase and NAD(P)dependent methylene $\mathrm{H}_{4} \mathrm{MPT}$ dehydrogenases were found in Methylobacillus flagellatus $\mathrm{KT}^{\mathrm{T}}$ (Vorholt et al., 1999).
The absence of the serine pathway-specific enzymes (hydroxypyruvate reductase and serine-glyoxylate transaminase) and the ribulose-bisphosphate pathway enzyme (ribulosebisphosphate carboxylase) means that their operation can be excluded in the case of the methylotroph studied.

The tricarboxylic acid cycle is deficient in 2-oxoglutarate dehydrogenase. The absence of isocitrate lyase and malate synthase indicates the non-functional glyoxylate shunt in strain $\mathrm{F} 31^{\mathrm{T}}$. Oxaloacetate is replenished by phosphoenolpyruvate carboxylase. Primary ammonia assimilation occurs by reductive amination of 2-oxoglutarate to glutamate, since the glutamine synthetase/glutamate synthase pathway (GS/ GOGAT) is not operative in this organism.

In the phylogenetic tree derived from $16 \mathrm{~S}$ rRNA gene sequences (Fig. 2), strain $\mathrm{F} 31^{\mathrm{T}}$ consistently branched with the $\beta$-Proteobacteria. The relatively high level of $16 \mathrm{~S}$ rRNA gene sequence similarity (95-97\%) between the strain and members of the genus Methylobacillus indicated a close relationship. The level of DNA relatedness between the novel isolate and reference strains of the genus Methylobacillus (Methylobacillus glycogenes ATCC $29475^{\mathrm{T}}$ and Methylobacillus flagellatus DSM $6875^{\mathrm{T}}$ ) was in the range $28-34 \%$. Remarkably, strain $\mathrm{F} 31^{\mathrm{T}}$ had a very low degree of DNA hybridization (5-10\%) with members of the genera Methylophilus, Methylovorus and Methylophaga (Methylophilus methylotrophus NCIMB $10515^{\mathrm{T}}$, Methylovorus glucosotrophus ATCC $49758^{\mathrm{T}}$ and Methylophaga marina ATCC $\left.35842^{\mathrm{T}}\right)$. Consequently, strain $\mathrm{F} 31^{\mathrm{T}}$ is classified as the type strain of a novel Methylobacillus species, for which the name Methylobacillus pratensis sp. nov. is proposed (Table 3).

\section{Description of Methylobacillus pratensis sp. nov.}

Methylobacillus pratensis (pra.ten'sis. L. masc. adj. pratensis means growing in a meadow).

Gram-negative rods that are $0 \cdot 9-1 \cdot 8 \times 0 \cdot 5-0 \cdot 7 \mu \mathrm{m}$ in size. Multiply by binary fission. Cells are motile by means of a single polar flagellum. Colonies on mineral salts/methanol agar are white and 1-2 $\mathrm{mm}$ in diameter. Strictly aerobic. Growth factors not required. Able to grow at $10-37^{\circ} \mathrm{C}$, at pH $5 \cdot 5-8 \cdot 5$ and optimally at $25-30{ }^{\circ} \mathrm{C}$ and $\mathrm{pH} 6 \cdot 5-7 \cdot 5$. Urease-, catalase- and oxidase-positive. Nitrate is reduced to nitrite. Produces indole (indole 3-acetic acid) from tryptophan on medium with nitrate as nitrogen source. No growth occurs in the presence of $3 \%(w / v) ~ N a C l$. Obligate methylotroph that utilizes only methanol and methylamine. Methylamine is oxidized to formaldehyde by the $\mathrm{N}$ methylglutamate pathway enzymes, $\gamma$-glutamylmethylamide synthetase and $\mathrm{N}$-methylglutamate synthase/lyase. Formaldehyde is assimilated via the RuMP pathway (EntnerDoudoroff variant). Ammonia is assimilated by glutamate dehydrogenase. Tricarboxylic acid cycle is incomplete at the level of 2-oxoglutarate dehydrogenase; the glyoxylate shunt enzymes are absent. Nitrates, ammonium salts, methylamine, glutamate and urea serve as nitrogen sources. The prevailing cellular fatty acids are $\mathrm{C}_{16: 0}$ and $\mathrm{C}_{16: 1}$. 
Table 2. Enzyme activities in cell extracts of strain $\mathrm{F} 31^{\top}$ when grown on different substrates

Activities are given as nmol $\mathrm{min}^{-1}$ (mg protein $)^{-1}$. Abbreviations: PMS, phenazine methosulfate; GSH, reduced glutathione; PEP, phosphoenolpyruvate. There was no activity with any of the following enzymes and cofactors: methylamine dehydrogenase (PMS), amine oxidase, $\gamma$-glutamylmethylamide lyase, hydroxypyruvate reductase $\mathrm{NAD}(\mathrm{P}) \mathrm{H}$, serine-glyoxylate transaminase $\mathrm{NAD}(\mathrm{P}) \mathrm{H}$, ribulose-bisphosphate carboxylase, isocitrate lyase, malate synthase, fructose-bisphosphate aldolase, 6-phosphofructokinase (ATP), pyruvate kinase, 2-oxoglutarate dehydrogenase, glutamate synthase, glutamine synthetase $\left(\mathrm{Mn}^{2+}\right.$, ATP).

\begin{tabular}{|c|c|c|c|}
\hline Enzyme & Cofactor(s) & Methanol & Methylamine \\
\hline Methanol dehydrogenase & PMS & 215 & 0 \\
\hline$\gamma$-Glutamylmethylamide synthetase & ATP, $\mathrm{Mn}^{2+}$ & 0 & 27 \\
\hline $\mathrm{N}$-Methylglutamate synthase & & 0 & 5 \\
\hline N-Methylglutamate lyase & & 0 & 3 \\
\hline \multirow[t]{2}{*}{ Formaldehyde dehydrogenase } & PMS & 0 & 0 \\
\hline & $\mathrm{NAD}^{+}, \mathrm{GSH}$ & 61 & 60 \\
\hline \multirow[t]{2}{*}{ Formate dehydrogenase } & PMS & 0 & 0 \\
\hline & $\mathrm{NAD}^{+}$ & 36 & 24 \\
\hline 3-Hexulosephosphate synthase & & 1400 & 1200 \\
\hline Phosphoriboisomerase & & 560 & 520 \\
\hline \multirow[t]{2}{*}{ Glucose-6-phosphate dehydrogenase } & $\mathrm{NAD}^{+}$ & 325 & 410 \\
\hline & $\mathrm{NADP}^{+}$ & 1090 & 1120 \\
\hline \multirow[t]{2}{*}{ 6-Phosphogluconate dehydrogenase } & $\mathrm{NAD}^{+}$ & 70 & 70 \\
\hline & $\mathrm{NADP}^{+}$ & 210 & 200 \\
\hline Hexokinase & ATP & 2 & 2 \\
\hline Transaldolase & & 40 & 40 \\
\hline Transketolase & & 174 & 162 \\
\hline 2-Keto-3-deoxy-6-phosphogluconate aldolase & & 125 & 130 \\
\hline Pyruvate dehydrogenase & $\mathrm{NAD}^{+}$ & 9 & 10 \\
\hline Citrate synthase & & 20 & 20 \\
\hline \multirow[t]{2}{*}{ Isocitrate dehydrogenase } & $\mathrm{NAD}^{+}$ & 94 & 92 \\
\hline & $\mathrm{NADP}^{+}$ & 81 & 79 \\
\hline \multirow[t]{2}{*}{ Glutamate dehydrogenase } & $\mathrm{NADH}$ & 130 & 110 \\
\hline & $\mathrm{NADPH}$ & 45 & 45 \\
\hline Pyruvate carboxylase & $\mathrm{Mg}^{2+}$ & 9 & 7 \\
\hline PEP carboxylase & Acetyl $\mathrm{CoA}, \mathrm{Mg}^{2+}$ & 2 & 2 \\
\hline PEP carboxykinase & ADP & 4 & 4 \\
\hline
\end{tabular}

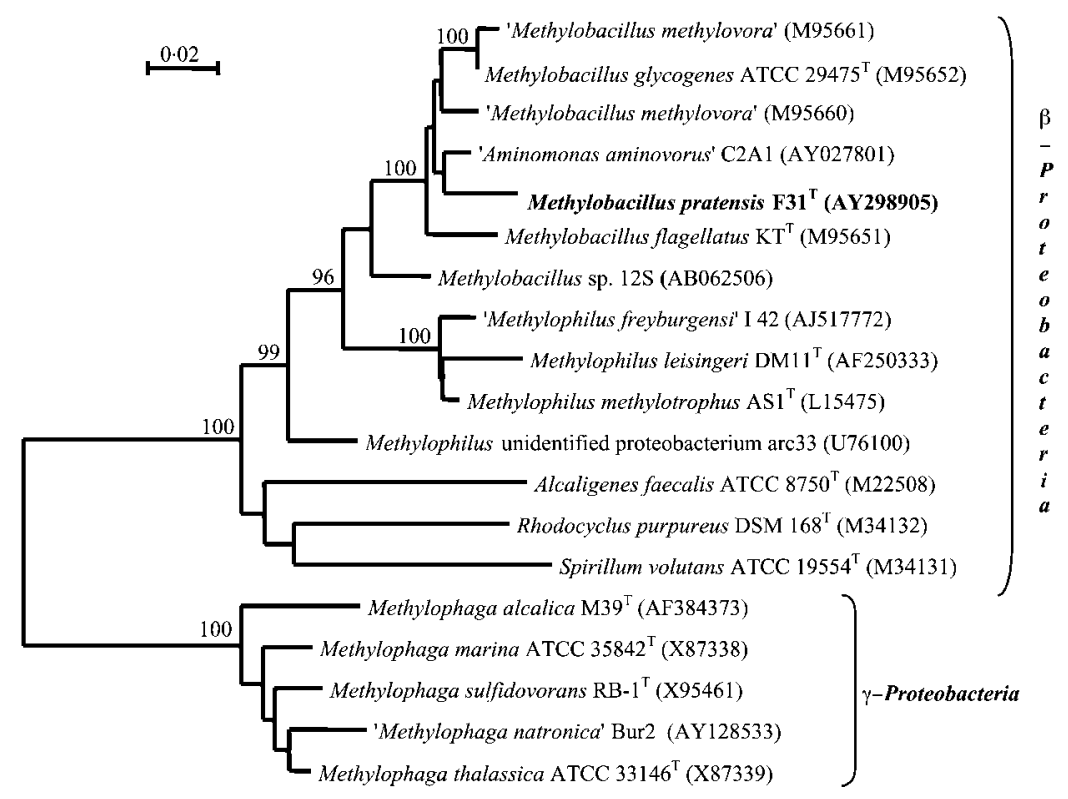

Fig. 2. Neighbour-joining tree showing the phylogenetic position of Methylobacillus pratensis $\mathrm{F} 31^{\top}$ among methylotrophs of the $\beta$-Proteobacteria. The numbers at the branch points are bootstrap values from 100 replicates. Bar, $2 \%$ Jukes-Cantor distance (2 nucleotide substitutions per 100 nucleotides; Jukes \& Cantor, 1969). 
Table 3. Major characteristics that allow differentiation among members of the genus Methylobacillus

Strain: 1, Methylobacillus pratensis $\mathrm{F}^{\mathrm{T}}{ }^{\mathrm{T}}$; 2, Methylobacillus glycogenes ATCC $29475^{\mathrm{T}}$; 3, Methylobacillus flagellatus DSM $6875^{\mathrm{T}}$. All data were obtained in this study.

\begin{tabular}{|c|c|c|c|}
\hline Characteristic & 1 & 2 & 3 \\
\hline Flagellation & 1 & - & $1-4$ \\
\hline Methylamine dehydrogenase & - & + & + \\
\hline$N$-Methylglutamate pathway & + & - & - \\
\hline Isocitrate dehydrogenase $\mathrm{NAD}^{+}$ & + & + & + \\
\hline Isocitrate dehydrogenase $\mathrm{NADP}^{+}$ & + & + & - \\
\hline \multicolumn{4}{|l|}{ Growth temp. $\left({ }^{\circ} \mathrm{C}\right)$ : } \\
\hline Range & $10-37$ & $10-35$ & $10-52$ \\
\hline Optimum & $25-30$ & $30-33$ & 42 \\
\hline DNA G $+\mathrm{C}$ content $(\mathrm{mol} \%)$ & $61 \cdot 5$ & $53 \cdot 2$ & $55 \cdot 5$ \\
\hline
\end{tabular}

The major ubiquinone is Q-8. Dominant phospholipids are phosphatidylethanolamine, phosphatidylglycerol and diphosphatidylglycerol (cardiolipin). Produces exopolysaccharide containing glucose, galactose and xylose. DNA $\mathrm{G}+\mathrm{C}$ content is $61 \cdot 5 \mathrm{~mol} \%\left(T_{\mathrm{m}}\right)$.

The type strain is $\mathrm{F} 31^{\mathrm{T}}\left(=\mathrm{VKM} \quad \mathrm{B}-2247^{\mathrm{T}}=\mathrm{NCIMB}\right.$ $13994^{\mathrm{T}}$ ), which was isolated from meadow grass (Poa trivialis L.) growing in Helsinki (Finland).

\section{Acknowledgements}

This work was supported by grant RFBR 03-04-49166 and by a grant (53305) from the Academy of Finland to the Microbial Resources Research Unit.

\section{References}

Doronina, N. V., Trotsenko, Y. A., Krausova, V. I., Boulygina, E. S. \& Tourova, T. P. (1998). Methylopila capsulata gen. nov., sp. nov., a novel non-pigmented aerobic facultatively methylotrophic bacterium. Int J Syst Bacteriol 48, 1313-1321.

Doronina, N. V., Darmaeva, T. D. \& Trotsenko, Y. A. (2003). Methylophaga alcalica sp. nov., a novel alkaliphilic and moderately halophilic, obligately methylotrophic bacterium from an East Mongolian saline soda lake. Int J Syst Evol Microbiol 53, 223-229.

Govorukhina, N. I. \& Trotsenko, Y. A. (1991). Methylovorus, a new genus of restricted facultatively methylotrophic bacteria. Int J Syst Bacteriol 41, 158-162.

Jenkins, O., Byrom, D. \& Jones, D. (1987). Methylophilus: a new genus of methanol-utilizing bacteria. Int J Syst Bacteriol 37, 446-448.

Jukes, T. H. \& Cantor, C. R. (1969). Evolution of protein molecules. In Mammalian Protein Metabolism, pp. 21-132. Edited by $\mathrm{H}$. N. Munro. New York: Academic Press.

Thompson, J. D., Higgins, D. G. \& Gibson, T. J. (1994). CLUSTAL W: improving the sensitivity of progressive multiple sequence alignment through sequence weighting, position-specific gap penalties and weight matrix choice. Nucleic Acids Res 22, 4673-4680.

Urakami, T. \& Komagata, K. (1986). Emendation of Methylobacillus Yordy and Weaver 1977, a genus for methanol-utilizing bacteria. Int $J$ Syst Bacteriol 36, 502-511.

Urakami, T. \& Komagata, K. (1987). Characterization of species of marine methylotrophs of the genus Methylophaga. Int J Syst Bacteriol 37, 402-406.

Van de Peer, Y. \& De Wachter, R. (1994). TREECON for Windows: a software package for the construction and drawing of evolutionary trees for the Microsoft Windows environment. Comput Appl Biosci 10, 569-570.

Vorholt, J. A., Chistoserdova, L., Stolyar, S. M., Thauer, R. K. \& Lidstrom, M. E. (1999). Distribution of tetrahydromethanopterindependent enzymes in methylotrophic bacteria and phylogeny of methenyl tetrahydromethanopterin cyclohydrolases. J Bacteriol 181, 5750-5757.

Yordy, J. R. \& Weaver, T. Y. (1977). Methylobacillus: a new genus of obligate methylotrophic bacteria. Int J Syst Bacteriol 27, 247-255. 